\title{
Implementing city-level carbon accounting: A comparison between Madrid and London
}

\author{
José Célio Silveira Andrade ${ }^{\mathrm{a}}$ *, Andrea Dameno ${ }^{\mathrm{b}}$, Javier Pérez ${ }^{\mathrm{b}}$, \\ Juan Manuel de Andrés Almeida ${ }^{\mathrm{b}}$, Julio Lumbreras ${ }^{\mathrm{b}}$ \\ ${ }^{a}$ Federal University of Bahia, Av. Reitor Miguel Calmon s/n, 40210-630, Salvador, Bahia, Brazil \\ ${ }^{\mathrm{b}}$ Technical University of Madrid, c/ José Gutiérrez Abascal 2, 28006, Madrid, Spain
}

\section{A R T I C L E I N F O}

\section{Article history:}

Received 28 April 2017

Received in revised form

2 October 2017

Accepted 15 October 2017

Available online 22 October 2017

\section{Keywords:}

City level carbon accounting

GHG inventory

Urban supply chain

Final consumers

Madrid

London

\begin{abstract}
A B S T R A C T
A change of focus from the current production-based Greenhouse Gas (GHG) emissions inventory to an integrated production-consumption carbon accounting system would improve the quality of city-level inventories. London is one of the few cities in the world which has reported its GHG emission inventory using Consumption-Based (CB) methodologies. Although Madrid has adopted the Global Protocol for Community-Scale Greenhouse Gas Emission Inventories (GPC) to report their GHG emissions, the city has never officially reported its GHG inventory using CB methodologies. Thus, the goal of this study is to analyze the challenges that must be faced by the production-based GHG emission inventory of Madrid in order to estimate GHG emissions from their supply chains and final consumers using the London's GHG emissions inventory experience. From the comparison between the 2010 GHG emission inventories of Madrid and London some challenges could emerge that Madrid's decision-makers might need to face regarding urban carbon accounting practices. As results, this paper shows that if GHG emissions from urban supply chains and final consumers are considered, the total GHG emissions reported by the Madrid inventory could double. This increase is similar to what London experienced when comparing production-based and integrated production-consumption GHG inventories. Besides, some difficulties related to lack of information were found when estimating GHG emissions associated with those goods and services consumed in Madrid. It would be useful to develop a full CB inventory using environmentally extended input-output (EEIO) matrices, more city-level primary data, and local cradleto-grave factors, following the methodology applied by the London inventory. These actions would allow a more accurate calculation of urban supply chains and final consumer GHG emissions in Madrid. Finally, further research is recommended in order to improve the current knowledge about the contributions of the energy, transport and waste sectors to GHG emissions in both, Madrid and London.
\end{abstract}

(C) 2017 Elsevier Ltd. All rights reserved.

\section{Introduction}

Making cities more sustainable is one of the most vital challenges of modern times, especially as they tend to have an increasing impact on the environment. Therefore, a greater emphasis placed on an integrated perspective on productionconsumption systems is needed in order to increase the quality of current urban Greenhouse Gas (GHG) emissions inventories (Hoornweg et al., 2011).

City-level carbon accounting standards are crucial to develop

\footnotetext{
* Corresponding author.

E-mail address: jcelio.andrade@gmail.com (J.C.S. Andrade).
}

good environmental management strategies. They enable city decision makers to clearly identify GHG emission sources and their drivers, reduce the carbon dependence of their economy, and encourage interventions aimed at achieving more efficient and sustainable urban supply chains and consumption-production systems (Schaltegger and Csutora, 2012).

Therefore, most of the city-level GHG inventories are carried out focusing on a production-based approach and they do not account for all the emissions embodied in goods and services consumed in a city. The large and increasing share of GHG emissions 'hidden' in imported goods and services underlines the importance of using consumption-based (CB) approach to develop city-level GHG emissions inventories (Andrade et al., 2017). 
The goal of this study is to analyze the challenges that must be faced by the production-based GHG emission inventory of Madrid in order to estimate GHG emissions from their supply chains and final consumers using the London's GHG emissions inventory experience.

These two cities were chosen due to a number of reasons. Firstly, on the one hand, London is one of the few cities in the world which has developed a CB GHG inventory following the guidelines of the British Specification for the Measurement of GHG Emissions of a City (PAS2070:2014) to report 2010 GHG emissions. The development of PAS2070 for reporting urban GHG emissions was made by the British Standards Institution (BSI), and it captures the direct GHG emissions as well as the indirect GHG emissions from goods and services (Greater London Authority, 2014).

On the other hand, Madrid has been computing productionbased GHG and other air pollutants emission inventories for more than 10 years, following both the Intergovernmental Panel on Climate Change (IPCC) 2006 guidelines and the 2013 European Air Pollutant Emission Inventory Guidebook (EEA, 2013). To do so, emission activities are classified according to the Selected Nomenclature for Air Pollution (SNAP) classification (Madrid, 2011a). The emission inventories that have been compiled over the years for Madrid have also been used to develop and monitor policies and measures to improve air quality in the city (Madrid, 2012, 2014, 2017). In 2015, Madrid decided to adopt other international standards such as the Global Protocol for CommunityScale Greenhouse Gas Emission Inventories (GPC) to report GHG emissions in 2012, but the city has not yet officially reported its GHG inventory using the PAS2070 framework (Madrid, 2015; Dameno, 2016).

Secondly, from the comparison between the 2010 GHG emissions inventories of these two cities, using $C B$ approach, some challenges emerged regarding the limitations in the effectiveness of local, national and global climate policies that regulate only the domestic production of emissions (Barrett et al., 2013). These could be of interest for Madrid's decision-makers to improve quality, completeness and effectiveness of urban carbon accounting practices and policies by changing their focus from the current production-based GHG inventory to an integrated productionconsumption carbon accounting system.

Thirdly, despite the growing importance of emissions linked to consumption, evidence on Carbon Footprint (CF) of cities remains scarce and comparisons between territorial and $\mathrm{CB}$ accounts are largely absent from literature (Kunanuntakij et al., 2017). Therefore, this study could contribute to fulfill this gap. Additionally, the 2010 GHG emission inventories of Madrid and London were chosen as they are publicly available, unlike most GHG inventories from cities in the world.

Finally, large cities like London and Madrid (the first and third populated cities in the European Union - EU, respectively) are considered to be more consumers of goods and services than producers and bringing down their CF could be a much bigger challenge than simply cutting their domestic emissions production (Minx et al., 2013). Therefore, this paper contributes to put into discussion the necessity of the cities to provide a more comprehensive estimation of their GHG emissions by switching the focus from traditional GHG inventories to an integrated productionconsumption carbon accounting system in order to account for their responsibility for both territorial and imported carbon emissions.

\section{Literature review}

GHG emissions inventories have become one of the most important tools to tackle climate change and meet the global Paris agreement's goal of holding the increase in the global average temperature under the $2{ }^{\circ} \mathrm{C}$ above pre-industrial levels threshold. The development of these emissions inventories has a long trajectory and, throughout several decades, GHG inventories have improved including more activity sectors and sub-sectors, and international standardized methodologies have been developed (WRI, 2014).

Normally, the existing methodologies have two distinct focuses: production-based inventories and $\mathrm{CB}$ inventories. While the former allocates GHG emissions to the producer, the latter allocates the emissions to the final consumer. Conceptually, CB inventories can be thought of as: consumption equals production-based emissions minus the emissions from the production of exports plus the emissions from the production of imports.

Traditional production-based methodologies were developed for national reporting and fail to account for GHG emissions occurring outside the study boundary but as a result of the activity of the territory (Schaltegger and Csutora, 2012). Furthermore, recent studies show that developed countries tend to be net importers of emissions whereas emerging and less developed countries tend to be net emissions exporters (Athanassiadis et al., 2016; Scott and Barrett, 2015).

This same trend can be found at the city level; production-based cities tend to become $\mathrm{CB}$ cities as they advance in their socioeconomic development (Mi et al., 2016). Thus, production-based approaches no longer reflect actual megacities GHG emissions, as they are more consumption centers than production entities (Athanassiadis et al., 2016).

While it is arguable that countries should publish $\mathrm{CB}$ inventories, in the case of cities it is indispensable to report their indirect GHG emissions, as production-based inventories do not provide a comprehensive measure of emissions linked to real activity at the city level (Ramachandra et al., 2015).

With the growing interest in accounting for indirect GHG emissions related to consumption activities within the cities in order to develop efficient environmental policies, cities, which are presumed to account for $70 \%$ of global energy-related GHG emissions, have become the focus of recently developed methodologies, such as: the PAS2070, developed by the London City Council together with the BSI in 2013; and the GPC, jointly developed by the World Resources Institute (WRI), the Local Governments for Sustainability (ICLEI) and the Cities Climate Leadership Group $\left(\mathrm{C}_{40}\right)$ in 2014.

The GPC is built upon the worldwide-used IPPC guidelines, which provide detailed guidance on data collection and calculation of GHG emissions, and it divides emission sources into scopes and sectors that have been globally adopted. This methodology has been adopted by many programs and initiatives including the Compact of Mayors, the Carbon Disclosure Project (CDP) reporting platform, the British standard PAS2070 and ISO37120:2014 (Sustainable Development of Communities).

The GPC methodology provides a framework for generating GHG emission inventories, where three scopes need to be objectively defined in order to cover all relevant GHG emissions (WRI, 2014):

- Scope 1, which accounts for GHG emissions from stationary energy, transportation, waste, Industrial Processes and Product Use (IPPU) and Agriculture, Forestry and Other Land Use (AFOLU) sources physically located within the city's boundary.

- Scope 2, which considers GHG emissions caused by consumption of grid-supplied electricity, heat, steam and/or cooling within the city's boundary.

- Scope 3, which accounts for GHG emissions outside the city's boundary as a consequence of activities that take place within 
the city boundary such as distribution losses associated with grid-supplied energy, waste generated in the city but disposed or treated outside the city boundary, out-of-boundary transportation and emissions embodied in consumed goods and services.

The GPC guidelines give cities the option of selecting between two reporting levels: BASIC or BASIC + . These levels cover specific scopes in different categories of activities, being the BASIC+ level the one that provides a broader analysis. The BASIC + reporting level includes the three BASIC categories (stationary energy, transportation and waste) and aggregates IPPU, AFOLU and any other emissions occurring outside the geographic boundary due to urban activities (WRI, 2014).

Thus, the GPC acted as a base to develop one of the two PAS2070 methodologies: the PAS 2070-DPSC (Direct Plus Supply Chain). It captures production-based emissions (consistent with emissions covered by BASIC and BASIC+ reporting levels of the GPC) plus emissions associated with the largest supply chains serving the cities: water supply, food and drink, and construction materials, specifically cement and steel (Table 1 ).

Unlike the PAS 2070-DPSC, the second PAS 2070 methodology (PAS2070-CB) captures life cycle GHG emissions for all goods and services consumed by the city, not only water, food and drink, and construction materials, allocating emissions to final consumers rather than to the original producers. The PAS2070-CB methodology sets out an approach to calculate GHG emissions linked to global and national supply chains with the use of EEIO (environmentally-extended input output) matrices.

EEIO analysis evaluates the emission impacts embodied in goods and services traded between nations, and it is recognized as one of the most appropriate tools to estimate $C B$ emissions accounts at a national and sub-national level (Scott and Barrett, 2015; Barrett et al., 2011). Although it may seem that this type of analysis has a larger uncertainty due to the incorporation of more input data, it has been found that the variation in CB estimates was less than the variation in production-based estimates (Barrett et al., 2013).

It is interesting to point out that, although there has not been much initiatives and researches regarding the development of EEIO matrices in order to look at CF on a city-level (Minx et al., 2013; Kunanuntakij et al., 2017), London has taken a global lead in including CB approach in an official GHG reporting inventory changing reported figures from 5.5 to $10-14.5 \mathrm{tCO}_{2} \mathrm{e}$ per capita when comparing domestic emissions production and PAS2070 (DPSC and CB) results (BSI, 2014). This fact is also observed in

Table 1

Sectors and sub-sectors in PAS2070-DPSC methodology.

\begin{tabular}{ll}
\hline Sectors & Sub-sectors \\
\hline Stationary Energy & $\begin{array}{l}\text { Residential buildings } \\
\text { Commercial, industrial and government } \\
\text { buildings and facilities } \\
\text { Road } \\
\text { Railways } \\
\text { Transport }\end{array}$ \\
& Water-borne navigation \\
& Aviation \\
IPPU & \\
AFOLU & Waste \\
Waste & Wastewater treatment \\
Goods and Services & Water supply \\
& Food and drink \\
& Construction materials (cement and steel)
\end{tabular}

Source: BSI (2013). several European cities, such as Oslo whose imports account for $45 \%$ of the city's CF (Larsen and Hertwich, 2010b), or Brussels who quadruples its GHG emissions when accounting the emissions associated with imported goods and services (Athanassiadis et al., 2016).

In seven United States' cities (Denver, Boulder, Ft. Collins, Arvada, Portland, Seattle, Minneapolis, and Austin) the addition of transboundary transport emissions to the emissions embodied in food and drink, fuels, cement and water increased on average a $47 \%$ the per capita GHG emissions (Hillman and Ramaswami, 2010).

A similar study for the largest five Australian cities (Sydney, Melbourne, Brisbane, Perth and Adelaide) using multi-region input-output (MRIO) modeling revealed that more than $50 \%$ of Australia's CF is attributable to consumption activities in those cities. Emissions embodied in imports (especially in the sectors of goods and services, construction, food and drink and electricity) made up 71\% of Sydney's CF and 55\% in Melbourne in 2009 (Chen et al., 2016a, 2016b).

A same pattern has been observed in China's cities. Mi et al. (2016) used an input output model to calculate CB emissions for thirteen Chinese cities and find substantial differences between $\mathrm{CB}$ and production GHG accounting in terms of both overall and per capita emissions: five are production based cities in which production based emissions exceed $C B$ emissions, whereas eight are $C B$ cities, with the opposite emissions pattern. From the perspective of final use, capital formation is the largest contributor to CB emissions from 32 up to $65 \%$. In Tianjin and Chongqing, for instance, more than half of $\mathrm{CB}$ emissions come from infrastructure investments: road construction, cement, steel and building materials consumptions, etc. (Meng et al., 2017).

In summary, it is important to know how urban sectors affect climate system by emitting GHG emissions. Mi et al. (2015a) have developed an optimization model based on EEIO matrices to assess the potential impacts of industrial structure on the energy consumption and GHG emission in Beijing, China. This study concluded that the industrial structure adjustment has great potential for energy conservation and carbon reduction. Also, raising the proportion of sectors which are low energy intensive and low carbon intensive is an effective method to save energy and reduce carbon emission. Lastly, the study states that energy intensity can be decreased without negatively affecting economic growth with reasonable industrial structure adjustment.

CB accounting has many advantages. It elucidates the drivers of emissions growth, improves cost-effectiveness and justice, promotes environmental comparative advantages, etc. (Mi et al., 2016). The largest disadvantage of $\mathrm{CB}$ emission inventories is that they require additional accounting and analysis. While some cities in the UK, Norway and the United States have started working with this methodology, in other countries such as Spain, EEIO or similar matrices have not yet been developed. (Barrett et al., 2011). For the case of Spain, there were some efforts to develop country-wide EEIO in 2000 and 2010, but studies are scarce and no work was continued (Morilla and Díaz-Salazar, 2004; Morilla, 2010). This instrument is also missing at Madrid's level, with no previous studies of this kind for the city. Therefore, policies set at a regional level fail to address the real challenges that the city faces in order to reduce GHG emissions.

According to Barrett et al. (2011), an integrated productionconsumption carbon accounting system is a key point for the development of competent low-carbon policies. Convergence between production and CB inventories should be seen as the best long-term solution for urban transformation towards decarbonized economies (Chen et al., 2016a).

The use of inappropriate methodologies and indicators results in inaccurate representations of city emissions, and it affects local 
climate change policy making (Ramachandra et al., 2015). It is therefore crucial to choose the appropriate methods and indicators to be used in climate change research. For instance, in order to put pressure on regions that perform poorly in mitigating climate change and highlight regions with best practice climate policies, $\mathrm{Mi}$ et al. (2015b) explored a method to assess regional efforts on climate change mitigation at sub-national level in China. This study developed a climate change mitigation index (CCMI) with 15 objective indicators that were divided into 4 categories: emissions, efficiency, non-fossil energy, and climate policy.

Cities such as Hong Kong, with an economy that produces few physical resources, but whose population import and consume large quantities of highly polluting products, have inefficient climate policies. Hong Kong's policies were agreed upon the result of $6 \mathrm{t} \mathrm{CO}_{2} \mathrm{e}$ per capita per year shown by a production-based inventory, figure that escalates to 9.2 when considering a CB methodology. For example, Hong Kong's consumption of imported forestry products, particularly wood and paper, are not included in the territory's official emissions inventory, despite the significant GHG emissions which are associated with these imports (Harris et al., 2012).

London and the UK have also experienced similar increases in their reported GHG emissions when taking into account consumption activities. In fact, differences between $\mathrm{CB}$ and production-based methodologies have followed an increasing tendency. From 1990 to 2008 the difference in growth between CB and production-based emissions was $23 \%$, the largest growth compared to other industrial nations in the top ten $\mathrm{CO}_{2}$ emitters (Barrett et al., 2011).

The success of GHG emissions reduction measures is offset by emissions generated in other regions to meet cities demand. Developed cities and countries are expected to remain net importers of emissions. By 2050, the UK's consumption emissions are estimated to be $43 \%$ higher than the target of cutting down emissions by $80 \%$ from 1990 levels if only current internationally pledged reductions were implemented (Scott and Barrett, 2015).

A focus on $\mathrm{CB}$ emissions highlights new policy options that may not be observed from a production perspective. From this traditional perspective, the main sources of emissions usually are energy production, energy-intensive industries and transportation, but a consumption perspective points towards manufactured products and consumed goods and services (Barrett et al., 2011; Peters, 2008). In order to show how limited the focus on only direct GHG emissions is, Larsen et al. (2012) identified that often $90 \%$ of mitigation strategies of the low-carbon policies are aimed at only $10 \%$ of the Norwegian cities' CF.

While in UK over $40 \%$ of CB service sector emissions are from the public sector, in Norway this figure changes to $15 \%$. This share is different for every country but it is assumed that the order of magnitude is maintained and the actions of the public sector are, therefore, essential to tackle climate change (Scott and Barrett, 2013; Larsen and Hertwich, 2010a, b, 2011).

It is in the hand of the government and public administration to take advantage of $\mathrm{CB}$ inventories that together with a good production-based analysis lead to more effective policy instruments; setting, at the same time, an example for GHG emissions' reduction in the private sector. Nevertheless, it has to be pointed out that taking a production perspective gives the impression of progress towards the global environmental objective, while a CB perspective shows the opposite (Barrett et al., 2011).

As policies of reducing emissions are bound to an increase in costs, abating countries will turn to non-abating countries to fulfill their demands and, therefore, the effort of some abating countries will be offset by an increase of emissions in non-abating countries
(Eichner and Pethig, 2009; Ramachandra et al., 2015).

Then, the carbon leakage is a recent phenomenon that is not taken into account when calculating GHG emissions based on a production-perspective point of view. This phenomenon is only detectable by using a $\mathrm{CB}$ perspective accounting which illustrates a more complete picture of the countries/cities carbon emissions on a global scale. As more industrial activities are outsourced to developing countries, local reduction of GHG emissions is not necessarily a sign of global GHG mitigation (Larsen and Hertwich, 2009) because one significant part of global $\mathrm{CO}_{2}$ emissions stem from the production of good that are consumed in a different country. However, traditional national GHG inventories do not include emissions associated with imported goods and partially present the true responsibility associated with a country's GHG mitigation actions (Davis and Caldeira, 2010).

For instance, the increased exports from China to the UK are a particularly key factor underlying the significant increase in the UK's CB emissions. In fact, the UK emissions are rising, once GHG emissions in imported goods (from China or elsewhere) are included (Barrett et al., 2011). As the domestic emissions production is the basis for countries climate policy, the reduction of emissions of some countries or cities, like UK and London, looks less impressive if they take in account the emissions related to imported goods and services.

Some studies focusing on Madrid reveal that the city is one of the largest consumers of electricity and fuel in the country (AEE, 2010). The consequences in terms of GHG emissions of the large amounts of energy that supply the city are accounted for in the traditional GHG inventory. However, a more integrated productionconsumption carbon accounting system would foster improvement of the city's environmental policies.

The comparison between London and Madrid is a perfect starting point for analyzing the current state of Madrid's inventory and presenting specific improvement actions that should be considered by the latter.

\section{Methodology}

As previously explained, PAS2070 standards provides a robust framework for generating CB GHG emission inventories. It captures indirect GHG emissions that were not accounted for in more traditional GHG inventories. As London has a detailed case study following PAS 2070 (DPSC and CB) methodologies, it was used as the reference for the calculation of Madrid's initial-stage PAS2070 GHG emission inventory in order to present a more realist figure of its GHG emissions.

In comparison to London, Madrid has not yet developed EEIO matrices at city-scale, it was not possible to use the PAS 2070-CB methodology. Then, for analyzing the other challenges faced by Madrid with regards to the PAS2070 London GHG experience, this study has estimated the Madrid's PAS2070 GHG emission inventory using only the PAS 2070-DPSC methodology.

In order to carry out this study, no primary sources were used. Instead, only secondary data from Madrid and London GHG inventories were collected from official and institutional documents for the year 2010 .

More specifically, the available 2010 secondary data from PAS 2070 application case study was used for London. Madrid, however, does not report its GHG inventory using the PAS2070 framework and only in 2015 it decided to adopt the GPC methodology to report its 2013 GHG emissions at BASIC and BASIC+ levels. Then, the available 2010 traditional production-based Madrid's GHG inventory, following the IPCC 2006 guidelines and the EMEP/EEA 2013 air pollutant emission inventory guidebook was used.

Table 2 provides basic information about Madrid and London. 
Table 2

Basic information about London and Madrid.

\begin{tabular}{|c|c|c|}
\hline & London & Madrid \\
\hline Year & 2010 & 2010 \\
\hline Description & $\begin{array}{l}\text { Capital of England and the United Kingdom; the } \\
\text { most populated city in the EU }\end{array}$ & $\begin{array}{l}\text { Capital of Spain; the third largest } \\
\text { city in the EU }\end{array}$ \\
\hline Area $\left(\mathrm{km}_{2}\right)$ & 1573 & 604 \\
\hline Population & $8,061,500$ & $3,273,049$ \\
\hline Gross Domestic Product - GDP (BN US\$) & 751.8 & 265.8 \\
\hline Minimum and Maximum average temperatures $\left({ }^{\circ} \mathrm{C}\right)$ & 6.7 and 13.1 & 8.4 and 20.6 \\
\hline
\end{tabular}

Source: Madrid (2011a) and Greater London Authority (2014).

They were used as references to estimate the PAS 2070 GHG emission inventories of these cities.

In order to make the comparison with London possible, the traditional production-based Madrid's GHG inventory was complemented with secondary data regarding consumption rates of goods and services collected from official documents of municipal and national governments as well as other private and public institutions and data bases.

The consumption data of water, construction materials (cement and steel), and food and drink were obtained from local and national statistical agencies. Some figures come from downscaling national per capita consumptions to Madrid's population. The Emission Factors (EF) were chosen from the life cycle inventory database (Ecoinvent 3.2, 2016) integrated in the Life Cycle Analysis (LCA) software package SimaPro 8.3 .0 (2016).

Tables 3 and 4 show the data used for calculating the Madrid's goods and services GHG emissions by the PAS 2070-DPSC standards.

The amounts of goods and services consumed as well as the EF used to calculate the associated GHG emissions for Madrid shown in Tables 3 and 4 are considered as low-quality data. Firstly, most of the good and services consumption figures are not specific for Madrid boundary. They have been scaled-down from national consumptions in most of the cases by considering population as surrogate. Secondly, EFs have a low reliability as most of them have been developed for Denmark and Central Europe. They are, however, the closest estimations available in Ecoinvent 3.2 (2016).

In order to confront and discuss the results of Madrid's and London's GHG emissions by using the PAS 2070-DPSC standards, the following indicators were used:

o Per capita GHG emission by traditional produced based inventory, GPC (BASIC and BASIC+), PAS 2070 (DPSC and CB) standards;

o Per capita urban and national GHG emissions;

o Per capita GHG emission by sector and subsector;

o Per capita stationary energy GHG emissions;

o Per capita transport GHG emissions;

o Per capita waste GHG emissions;

o Per capita goods and services GHG emissions.

Table 3

Water, cement and steel consumption data and emission factors used for Madrid.

\begin{tabular}{lll}
\hline Activity & Madrid's Consumption & Emission Factor \\
\hline Water & $210,932\left(10^{3}\right) \mathrm{m}^{3}$ & $0.15 \mathrm{~kg} \mathrm{CO} 2 \mathrm{e} / \mathrm{m}^{3}$ \\
& $(\mathrm{AEM}, 2010)$ & $($ Canal Isabel II gestión, 2013) \\
Cement & $1,724,158$ tonnes & $0.85 \mathrm{~kg} \mathrm{CO} 2 \mathrm{e} / \mathrm{kg}$ cement \\
& $($ Oficemen, 2011) & $($ Ecoinvent 3.2, 2016) \\
Steel & 942,540 tonnes & $2.03 \mathrm{~kg} \mathrm{CO} 2 \mathrm{e} / \mathrm{kg} \mathrm{steel}$ \\
& $($ UNESID, 2011) & $($ Ecoinvent 3.2, 2016) \\
\hline
\end{tabular}

As Lumbreras et al. (2009, 2015) point out, uncertainties are inevitable when the GHG emissions inventories are estimated. Therefore, an assessment of uncertainties related to GHG emissions inventories is important to provide useful information for policymakers about the potential limitations of the findings. For this purpose, there are many tools to carry out quantitative and qualitative uncertainty analysis.

In this work, there are important sources of uncertainties associated to Madrid's and London's GHG emissions results such as the uncertainties in the city-level emissions inventories; estimations techniques per se consist of a simplification that may not represent the reality and use of default, low-quality and surrogate data, especially for EF and amounts of goods and services consumed at city-level. However, no quantitative or qualitative methods were utilized for expressing the uncertainties of the results. It is a limitation of this study and further investigation is required.

\section{Results and discussions}

Table 5 shows the total GHG emission of London and Madrid inventories under PAS2070-DPSC methodology for 2010.

The evolution of GHG inventories is reflected in Fig. 1. It shows the increase of total GHG emissions with different methodologies from traditional production-based perspectives (including GPC reporting levels BASIC and BASIC + ) to PAS 2070 (DPSC and CB) methodologies. As previously explained, Madrid has not yet developed a CB inventory because EEIO matrices have not been found at city-scale and future research is recommended. Then, dotted lines showed in Fig. 1 represent an estimate for Madrid's total GHG emissions under PAS 2070-CB methodology.

The inclusion of consumed goods and services proved to be an improvement in the estimation of GHG emissions inventories. In the case of London and Madrid, GHG emissions increased by $74 \%$ and $112 \%$ respectively when comparing traditional approaches (BASIC + ) with ones that start including emissions linked to consumption (PAS 2070-DPSC).

This increase in reporting GHG emissions when consumption and transboundary activities are included is typical of developed cities that tend to be net importers of food and services. In fact, this relevant increase of emissions was also found in several cities in Norway that increased their figures by $30 \%$ (Larsen and Hertwich, 2009, 2010a).

In accordance with the previous analysis, Fig. 2 highlights that considering scope $3 \mathrm{GHG}$ emissions is the main responsible for the increase in per capita GHG emissions between PAS 2070-DPSC and others approaches: traditional and GPC (BASIC/BASIC+). According to these results, cities whose consumptions derive into the generation of $\mathrm{MtCO}_{2} \mathrm{e}$ must take into account the scope 3 emissions for reducing the urban effects on climate change.

London and Madrid, as capital cities of developed countries, are expected to have more GHG emissions associated with the 
Table 4

Food and drink consumption data and emission factors used for Madrid.

\begin{tabular}{|c|c|c|c|}
\hline Food and drink products & $\begin{array}{l}\text { Madrid's consumption in tonnes } \\
\text { (AEM, 2010; AEE, 2010) }\end{array}$ & $\begin{array}{l}\text { Emission Factor }\left(\mathrm{kgCO}_{2} \mathrm{e} / \mathrm{kg} \text { product) from }\right. \\
\text { Ecoinvent } 3.2(2016)\end{array}$ & Source inside Ecoinvent 3.2 (2016) \\
\hline Fruits & 749,825 & 0.34 & Project LCA Food Denmark (2007) \\
\hline Vegetables & 664,939 & 0.21 & \\
\hline Fresh fish & 83,201 & 1.32 & \\
\hline Fresh seafood & 15,297 & 2.96 & \\
\hline Frozen fish & 44,932 & 1.80 & \\
\hline Meat & 141,581 & 3.10 & \\
\hline Eggs & 49,921 & 0.21 & Universidad Sevilla (2011) \\
\hline Liquid milk & 264,568 & 0.001 & Project LCA Food Denmark (2007) \\
\hline Dairy & 4007 & 1.92 & \\
\hline Bread & 97,571 & 0.83 & \\
\hline Pastries & 46,339 & 0.77 & \\
\hline Cocoa & 9393 & 0.22 & Universidad Sevilla (2011) \\
\hline Coffee and tea & 5517 & & \\
\hline Rice & 12,184 & 2.00 & Project LCA Food Denmark (2007) \\
\hline Pasta & 11,691 & & \\
\hline Sugar & 1445 & 0.96 & \\
\hline Legumes & 10,082 & 0.25 & Universidad Sevilla (2011) \\
\hline Oil & 39,738 & 3.43 & Project LCA Food Denmark (2007) \\
\hline Olive oil & 31,462 & 2.62 & Oilca $(2012)$ \\
\hline Sunflower oil & 7455 & 6.49 & Agri-footprint (2010) \\
\hline Butter & 2562 & 0.02 & Project LCA Food Denmark (2007) \\
\hline Alcoholic beverages & 29,261 & 10.95 & EU27 of project \\
\hline Non-alcoholic beverages & 154,911 & & EU\& Denmark Input Output Database (2012) \\
\hline
\end{tabular}

Table 5

Total GHG emissions of London and Madrid in 2010 in $\mathrm{MtCO}_{2} \mathrm{e}$ under PAS2070-DPSC guidelines.

\begin{tabular}{|c|c|c|c|c|c|c|c|c|c|}
\hline \multirow[t]{3}{*}{ Sector } & & \multicolumn{4}{|c|}{ London 2010} & \multicolumn{4}{|c|}{ Madrid 2010} \\
\hline & & \multicolumn{4}{|c|}{ GHG emissions million $\mathrm{tCO}_{2} \mathrm{e}$} & \multicolumn{4}{|c|}{ GHG emissions million $\mathrm{tCO}_{2} \mathrm{e}$} \\
\hline & & Scope 1 & Scope 2 & Scope 3 & Total & Scope 1 & Scope 2 & Scope 3 & Total \\
\hline \multirow[t]{3}{*}{ Stationary } & Residential buildings & 9.34 & 6.79 & 2.52 & 18.64 & 1.63 & 1.38 & 0.58 & 3.59 \\
\hline & Commercial, industrial and government buildings and facilities & 5.36 & 12.74 & 3.48 & 21.58 & 1.21 & 3.02 & 0.81 & 5.04 \\
\hline & Sub-total & 14.69 & 19.53 & 5.99 & 40.21 & 2.84 & 4.40 & 1.39 & 8.63 \\
\hline \multirow[t]{5}{*}{ Transport } & Road & 6.13 & 0.00 & 2.79 & 8.92 & 2.69 & 0.00 & 0.35 & 3.04 \\
\hline & Railways & 0.13 & 1.10 & 0.31 & 1.53 & 0.01 & 0.34 & 0.09 & 0.44 \\
\hline & Water-borne navigation & 0.02 & 0.00 & 0.02 & 0.04 & 0.00 & 0.00 & 0.00 & 0.00 \\
\hline & Aviation & 0.98 & 0.00 & 13.74 & 14.72 & 0.65 & 0.00 & 7.31 & 7.96 \\
\hline & Sub-total & 7.26 & 1.10 & 16.86 & 25.21 & 3.34 & 0.34 & 7.75 & 11.44 \\
\hline IPPU & Sub-total & 1.91 & & & 1.91 & 0.73 & & & 0.73 \\
\hline AFOLU & Sub-total & 0.03 & & & 0.03 & -0.02 & & & -0.02 \\
\hline \multirow[t]{3}{*}{ Waste } & Waste & 0.18 & & 0.42 & 0.60 & 0.36 & & 0.00 & 0.36 \\
\hline & Wastewater treatment & 0.02 & & 0.03 & 0.05 & 0.09 & & 0.00 & 0.09 \\
\hline & Sub-total & 0.20 & & 0.46 & 0.66 & 0.45 & & 0.00 & 0.45 \\
\hline \multirow[t]{4}{*}{ Goods and services } & Water & 0.00 & & 0.04 & 0.04 & 0.00 & & 0.01 & 0.01 \\
\hline & Food and drink & 0.01 & & 10.71 & 10.71 & 0.00 & & 3.55 & 3.55 \\
\hline & Construction & 0.00 & & 2.27 & 2.27 & 0.00 & & 3.38 & 3.38 \\
\hline & Sub-total & 0.01 & & 13.02 & 13.03 & 0.00 & & 6.93 & 6.93 \\
\hline Total & & 24.11 & 20.62 & 36.33 & 81.06 & 7.33 & 4.74 & 16.08 & 28.16 \\
\hline
\end{tabular}

Source: Developed by the authors from data of Madrid (2011a) and Greater London Authority (2014).

consumption of goods and services than with their production. The PAS 2070-DPSC methodology which accounts for these emissions clearly reflects the effects of the consumption levels on total carbon emissions of both cities.

If we confront London's and Madrid's traditional GHG emissions with those of UK and Spain using domestic emissions productionbased methodologies, the results show that these cities have lower emission rates than national averages. But if PAS 2070-CB inventories are used, the results show an inverse trend: urban emissions rates are higher than national ones (see Fig. 3).

Data from Fig. 3 corresponds to year 2010 except for the value of Spain's GHG under CB methodology. The $11.68 \mathrm{tCO}_{2} \mathrm{e}$ per capita of
Spain represented in the last bar correspond to year 2005 as it was the only figure that could be found in literature (CAR PL, 2008).

Total GHG emissions for UK and Spain under PAS 2070-DPSC methodology as well as Madrid's total GHG emissions under PAS 2070-CB methodology are not available publicly and, therefore, a rough approximation for these numbers has been plotted in Fig. 3 using dotted-line bars.

The observed relationship between London's and Madrid's emissions and national averages is similar to the results of the analysis of Harris et al. (2012) regarding Hong Kong's emissions when taking into account scope 3 GHG emissions from some consumption activities. 


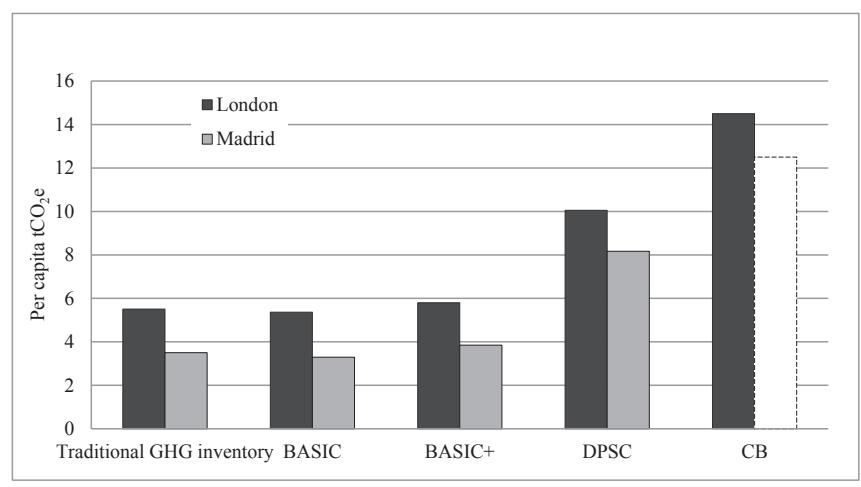

Fig. 1. Per capita GHG emissions by different methodologies.

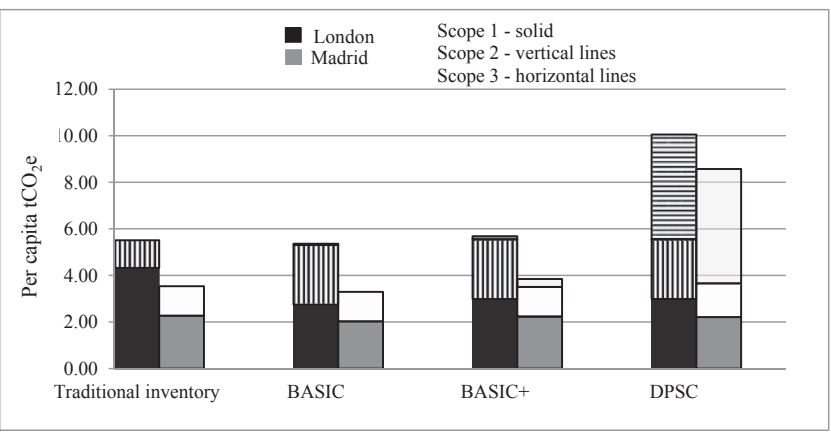

Fig. 2. Per capita GHG emissions by scope and methodology.

Meng et al. (2017) point out a correlation between GHG emissions and levels of socio-economic development. London, with higher per capita GDP, shows higher per capita emissions than Madrid.

As stated by Minx et al. (2013) the increases in average income of municipalities rise the $\mathrm{CF}$. In general terms, wealthy cities tend to have a higher CF per capita compared to less wealthy cities when all other factors remain constant (Larsen and Hertwich, 2011, 2010a).

The disaggregation of per capita emissions by different sectors and sub-sectors illustrates the differences between the two European cities analyzed (see Figs. 4 and 5). Large differences are found in stationary energy (both in residential and commercial buildings) and goods and services. Also, some differences are observed in transport (mainly in aviation and road transportation). All these

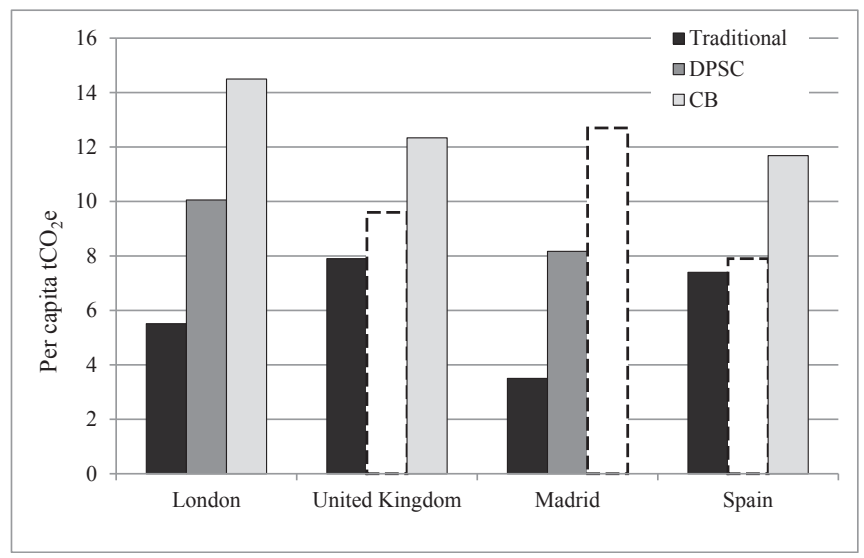

Fig. 3. National and urban per capita GHG emissions. differences are inherent to the different civil, cultural and economic structures of the cities.

Taking a closer look to goods and services, which is the most recent developed part of the PAS 2070-DPSC methodology, a significant difference is observed in per capita emissions between London $\left(1.615 \mathrm{tCO}_{2} \mathrm{e}\right)$ and Madrid $\left(2.119 \mathrm{tCO}_{2} \mathrm{e}\right)$. Both cities have quite similar consumption cultures. Thus, it would be expected that Madrid with lower per capita GDP would have lower consumption rates and, therefore, lower per consumption-related capita GHG emissions. The unexpected result could be related mainly to the emissions linked to the different EF for the construction materials consumed (see Fig. 5) and is deeper analyzed later.

Regarding stationary energy, Fig. 6 illustrates a significant difference in total GHG emissions per capita while similar emission allocation to residential buildings and other (commercial, industrial, and government) buildings.

Differences regarding stationary GHG emissions between these two cities could be associated with the discrepancy in maximum and minimum average temperatures (see Table 2); the disparity of heating, cooling and insulation systems; and the substantial variance in grid-supplied electricity EF: London is $0.524 \mathrm{ktCO}_{2} \mathrm{e} / \mathrm{GWh}$ (Greater London Authority, 2014), significantly higher than the $0.292 \mathrm{ktCO}_{2} \mathrm{e} / \mathrm{GWh}$ of Madrid (2011a).

Fig. 7 points out the role that indirect emissions play in the sector of stationary energy, as in both cities scopes 2 and 3 emissions account for more than $60 \%$ of total $\mathrm{CO}_{2} \mathrm{e}$ emitted.

Focusing on transportation GHG emissions, Madrid has a slightly higher per capita emission rate than London caused by a significant difference in GHG emissions from aviation transportation (see Fig. 8). This is an unexpected result as London has larger airport activity than Madrid. In fact, Heathrow airport obtained in 2010 the rank of first busiest European airport, with 66 million of passengers (CAA, 2017), whereas Barajas airport in Madrid was considered the fourth one, with 50 million of passengers in 2010 (AENA, 2017). However, it can be observed that Madrid's inclusion of transboundary transportation activity has increased disproportionately its aviation GHG emissions. Therefore, the contribution of aviation to climate change is considerably uncertain because of the complexity and different methodologies for its estimation and the allocation of emissions between origins and destinations. In fact, cities with intense aviation activity like Hong Kong can report up to one quarter of its total GHG emissions under this sector if transboundary transportation is taken into account (Harris et al., 2012).

Concerning factors affecting road transportation and consequently per capita GHG emissions, there are several studies showing a close link to geographic characteristics, urban layout and

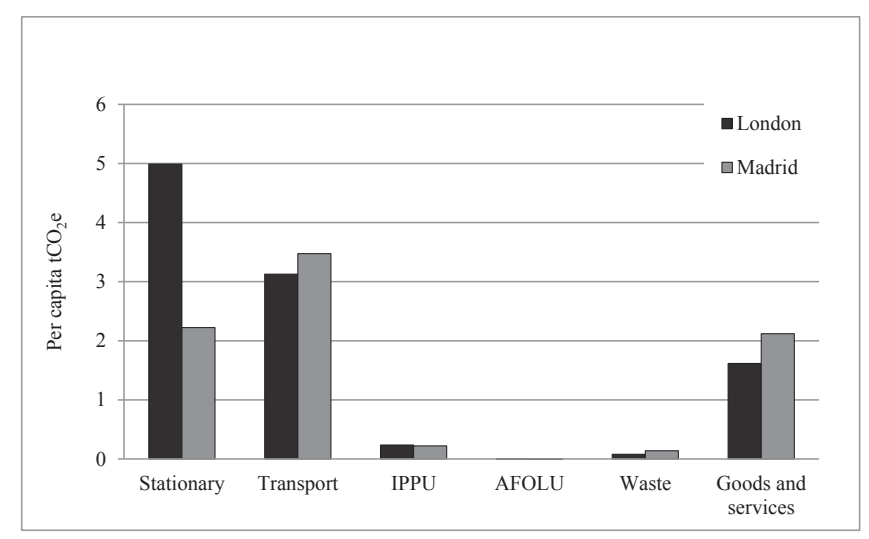

Fig. 4. Per capita GHG emissions by sector. 


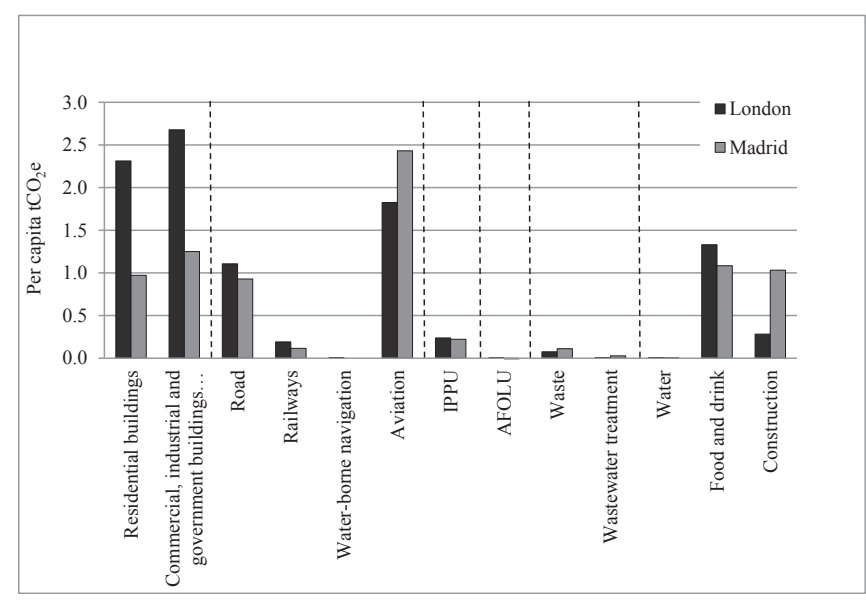

Fig. 5. Per capita GHG emissions by sub-sector.

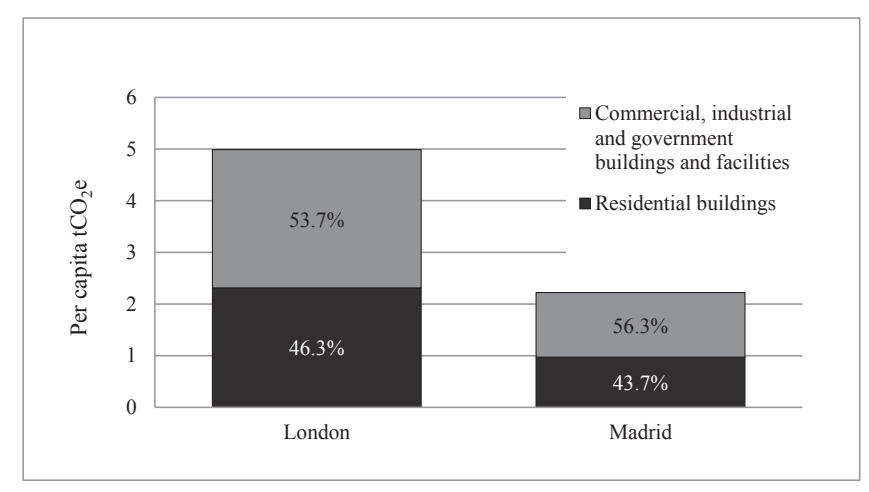

Fig. 6. Stationary energy GHG emissions by sub-sector.

population density. Larsen and Hertwich (2011) state that in Norway the five highest $\mathrm{CO}_{2}$ emitting counties (Sogn of Fjordane, Finnmark, Nordland, Nord-Trøndelag and Troms) have in common a low population density. This statement of an inverse relationship between population density and CF was also found in the cities of UK by Minx et al. (2013), and the cases of Madrid and London comply with that hypothesis.

As for the waste sector, it may not seem as important because of the lower GHG emission rates associated with it. However, as Perez et al. (2017a, b) defend, waste and wastewater management strategies are one of the main focus of cities' policies to mitigate their GHG emissions as it is a local governmental duty.

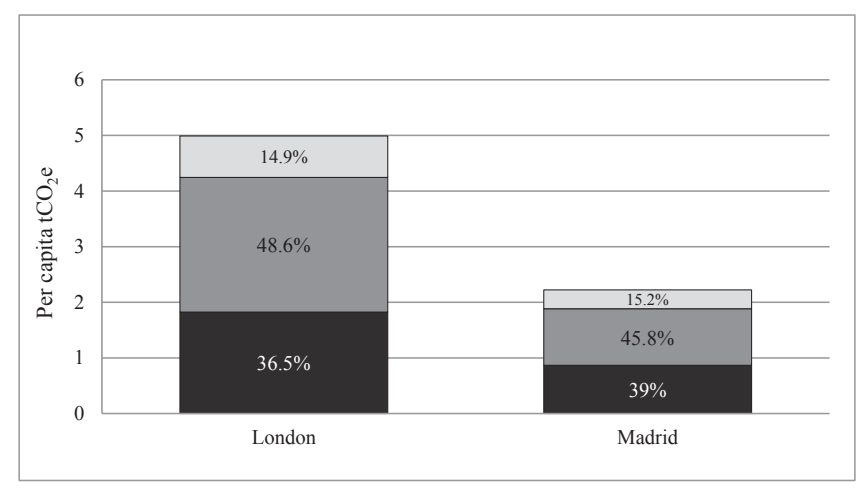

Fig. 7. Stationary energy GHG emissions by scope.

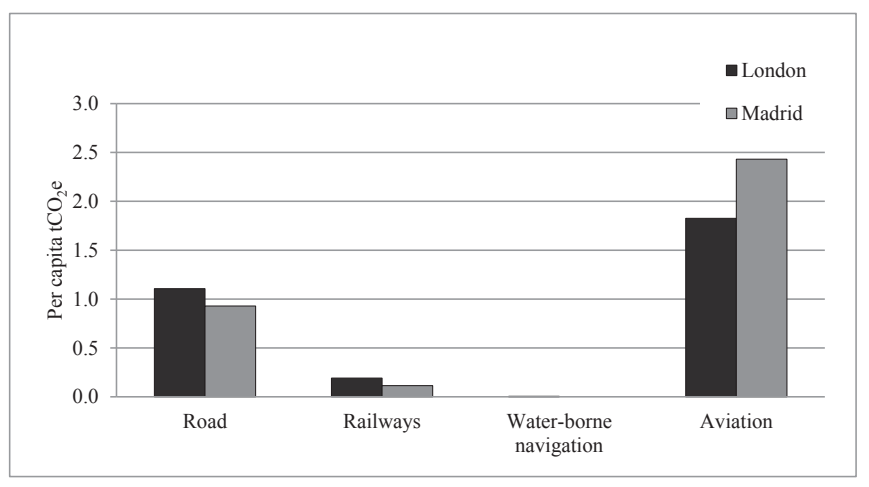

Fig. 8. Transportation GHG emissions by sub-sector.

Madrid accounts for more per capita waste GHG emissions than London and it is observed that the biggest difference comes mainly from the GHG emissions associated with landfill treatment (see Fig. 9). Landfill emissions vary with several factors including share of organic matter, temperature, age of the landfill, and calculation methodology.

Regarding waste treatment technologies, Madrid deposits 56\% of its waste in landfills and London 49\%. London incinerates more waste as compared to Madrid and, therefore, accounts for higher incineration emissions.

Fig. 9 also shows a much larger emission of GHG in Madrid from wastewater treatment. Several hypotheses could explain the difference, including a bigger capture of biogas in London as compared to Madrid (Greater London Authority, 2011; Madrid, 2011b).

As presented in the literature review, the PAS2070-DPSC methodology includes a new sector of GHG emissions linked to consumption of goods and services. Fig. 10 shows the differences regarding GHG emissions of the subsectors for this category.

It can be observed that construction GHG emissions are very different for London and Madrid. The dissimilarity could be associated with a difference in consumption rates and, most probably, with the low representativeness of the EF of cement and steel used for Madrid. These factors were not available at city-scale level and they were taken from SimaPro 8.3.0 (2016).

Also, it is interesting to point out that the per capita GHG emissions from main water supply to both cities account for very small numbers $\left(0.005 \mathrm{tCO}_{2} \mathrm{e}\right.$ in Madrid and $0.002 \mathrm{tCO}_{2} \mathrm{e}$ in London). It is happening because, according the PAS2070-DPSC methodology, the subsector of water supply (see Table 1) accounts only the GHG emissions produced as a result of the energy used to distribute water. However, all the GHG emissions derived from the use of energy to produce drinking water within the boundaries of the city are already taken into account in the sector of stationary energy. Therefore, the GHG emissions related to water presented in the sector of goods and services are those one produced from the energy used to transport the water from its sources (dams, reservoirs, etc.) to the boundaries of the cities.

This first approximation to calculate emissions associated with consumption in Madrid proved that a significant amount of GHG emissions (6.93 million $\mathrm{tCO}_{2} \mathrm{e}$ ) were missing from the inventory. Madrid, as other cities in developed countries, is an importer of embodied emissions that make up almost the 25\% of total GHG emissions reported following the PAS2070-DPSC methodology.

\section{Conclusions}

Madrid has developed GHG emissions inventories over the last decade but using a methodology that fails to provide an adequate 


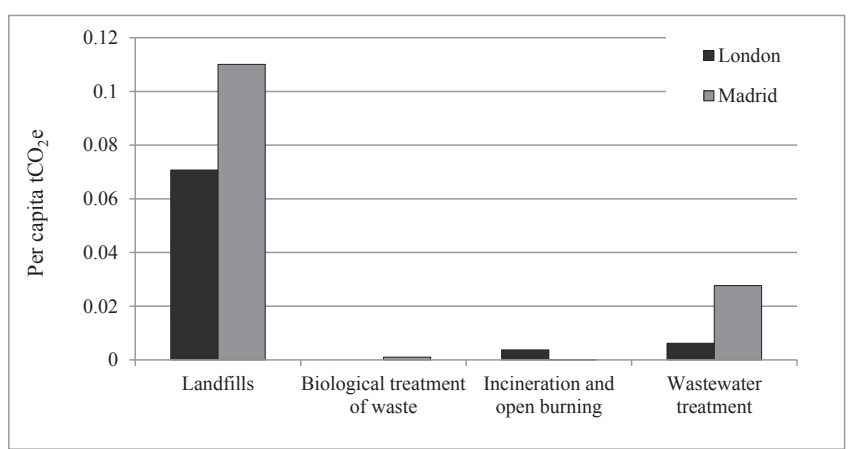

Fig. 9. Waste GHG emissions by sub-sector.

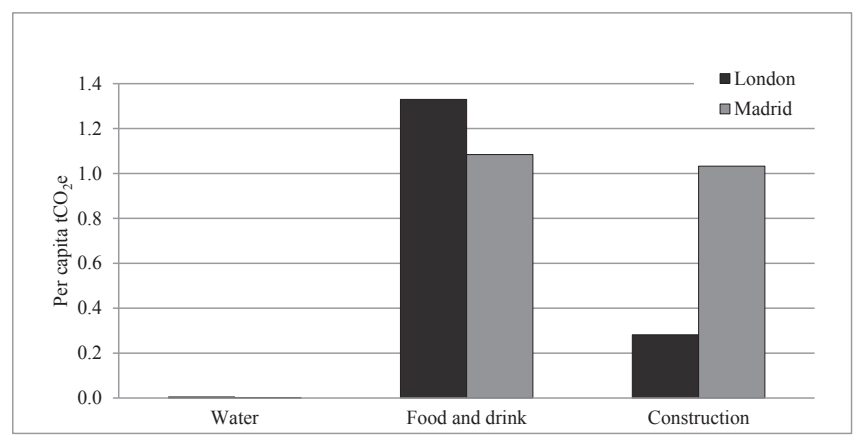

Fig. 10. Goods and services GHG emissions.

guide to the comparative climatic impact of consumption patterns within the territory. As a result, Madrid and other cities around the world have underestimated its contributions to climate change.

Using London's PAS2070 GHG emission inventory experience as reference, this study shows that, according to Direct Plus Supply Chain (DPSC) standard, which include indirect emissions from consumption of goods and services, Madrid doubles their total GHG emissions reported by the traditional production-based inventory. Therefore, there is a need to cut imported emissions as well as those produced in the cities.

Some implications were revealed by the comparison between the 2010 GHG emissions inventories of these two cities: i) focusing GHG inventories and climate policies on domestic production fails to address the climate impact of imported carbon emissions and contributes to the infectiveness of carbon reduction actions; ii) as an integrated production-consumption approach provides a more comprehensive figure about the cities/countries emissions on a global scale, it is more appropriated to drive the low-carbon policies, considering the fact that climate change is a phenomenon with global impacts. Thus, it is vital that cities/countries make efforts to measure not just their domestic production of emissions but also the emissions associated with the consumption and use more realistic data to drive their climate policies; iii) $\mathrm{CB}$ approach to measuring the CF of cities and countries is an idea that if applied internationally would have implications for global climate politics, creating a fairer basis for international negotiations and contributing to the increase the effectiveness of the global climate policies.

Some limitations were found during this study. Public data regarding GHG emissions under PAS 2070-DPSC standards were not found for UK and Spain in the literature. Similarly, Consumption Based (CB) GHG emissions for Madrid were missing. Only available secondary data for 2010 were utilized for comparing the GHG emissions inventories of the two cities. Also, the results cannot be compared to previous years and, even though basic relationships comparing the two cities have been met, it is not possible to defend the accuracy of the results. Estimations made in this study in order to fulfill these limitations constitute a first approach and have low certainty. GHG emissions inventories should include uncertainty estimations to aid the decision-making process. Thus, further investigation is required in order to decrease and assess the uncertainties associated with the city-level GHG emissions inventories.

These evidences suggest that Madrid should look beyond a production perspective, and should address the productionconsumption systems to improve its GHG inventory. The following two challenges are faced by Madrid regarding the development of an integrated production-consumption GHG inventory:

1) Development of a CB methodology. National-scale input-output models are not yet mature for Spain, and little is known about city-level input-output models. London has developed a full PAS 2070-CB inventory helped by EEIO matrices, which was impossible to compare to Madrid as the Spanish capital lacks this kind of analytic tool. Therefore, further lines of research should be directed towards developing EEIO matrices for the city of Madrid, that would give a holistic view of the city and could promote implementation of low-carbon policies addressing consumed goods and services.

2) Improvement of the cities' statistic information systems in order to provide disaggregated and high-quality data at a local scale. Significant amounts of data need to be collected to conduct a city-level GHG inventory. Normally, some of them are not available at city-level. For example, in this study, national average $\mathrm{EF}$, foreign cradle-to-grave factors, and national or regional data downscaled from national consumption in most cases considering population as surrogate were used instead of city-level data. This is an important source of uncertainties associated to the Madrid's GHG emissions inventory.

Additionally, considering that activities in urban sectors affect the climate system by emitting GHG emissions, while climate change has impacts on urban sectors, further research is recommended in order to improve knowledge about contributions of the following urban sectors to GHG emissions in Madrid and London (and their associated uncertainties):

1) Heating, cooling and insulation systems, including to what extent the difference in electricity EF can affect stationary energy GHG emissions;

2) Transboundary aviation emissions, taking into account the activity of international airports;

3) Waste management, as one of the main responsibilities for local public administrations around the world. Since there are significant differences on emissions depending on the waste management system, further studies are recommended to show lessons learnt from low emission cities.

Finally, it would also be interesting to expand this study to other European cities. A comparison between different EU cities could show trends in consumption habits that have high-intensity GHG emissions. It could also help to develop inter-European policies that would contribute to reduce carbon leakage and CB GHG emissions.

\section{Acknowledgments}

This study would not have been possible without the cooperation of staff of the Laboratory for Chemical Technology and 
Environmental Modeling Laboratory of the Technical University of Madrid. The authors express their special appreciation to the reviewers for their constructive and useful comments. Finally, thanks to Madrid City Council for relevant data provided and Brazilian National Council for Scientific and Technological Development for the scholarship awarded to the first author.

\section{References}

Andrade, C., Dameno, A., Perez, J., Andres, J.M., Lumbreras, J., 2017. Comparing Madrid and Salvador GHG emission inventories: implications for future researches. J. Oper. Supply Chain Manag. 10 (1), 17-32.

AEE (Anuario Estadístico de España), 2010. Estadísticas de Consumo. Ministerio de Agricultura y Pesca, Alimentación y Medio Ambiente. http://www.mapama.gob. es/estadistica.aspx. (Accessed 15 December 2016).

AEM (Anuario Estadístico Madrid), 2010. Estadísticas de Consumo. Madrid City Council. http://www.madrid.es. (Accessed 15 November 2016).

AENA (Aeropuertos Españoles y Navegación Aérea), 2017. Estadísticas de Tráfico Aéreo. http://www.aena.es/csee. (Accessed 10 March 2017).

Athanassiadis, A., Christis, M., Bouillard, P., Vercalsteren, A., Crawford, R.H., Khan, A.Z., 2016. Comparing a territorial-based and a consumption-based approach to assess the local and global environmental performance of cities. J. Clean. Prod. https://doi.org/10.1016/j.jclepro.2016.10.068.

Barrett, J., Le Quéré, C., Lenzen, M., Peters, G., Roelich, K., Wiedmann, T., 2011. Consumption-based Emissions Reporting. https://www.publications. parliament.uk/pa/cm201012.htm. (Accessed 17 February 2017).

Barrett, J., Peters, G., Wiedmann, T., Scott, K., Lenzen, M., Roelich, K., Le Quéré, C., 2013. Consumption-based GHG emission accounting: a UK case study. Clim. Policy 13 (4), 451-470. https://doi.org/10.1080/14693062.2013.788858.

BSI (British Standards Institution), 2013. PAS2070:2013 Specification for the Assessment of GHG Emissions of a City: DPSC and CB Methodologies. http:// shop.bsigroup.com/PASs.pdf. (Accessed 12 June 2016).

BSI (British Standards Institution), 2014. Application of PAS2070 - London, UK: an Assessment of GHG Emissions of a City. http://shop.bsigroup.com/upload/ PAS2070_case_study_bookmarked.pdf. (Accessed 12 June 2016).

CAA (Civil Aviation Authority), 2017. UK airport Data. http://www.caa.co.uk/Dataand-analysis/UK-aviation. (Accessed 12 June 2016).

Canal Isabel II gestión, 2013. Informe Anual 2012. https://www. canaldeisabelsegunda.es/galeria_ficheros.pdf. (Accessed 10 March 2017).

CAR PL Centro de Actividad Regional para la Producción Limpia, 2008. Las emisiones de gases de efecto invernadero desde la perspectiva del consumo en una economía global: Estudio de caso Espana. Barcelona, Espana. https://globalcad. org. (Accessed 12 May 2016).

Chen, G., Hadjikakou, M., Wiedmann, T., 2016a. Urban carbon transformations: unravelling spatial and inter-sectoral linkages for key city industries based on multi-region input-output analysis. J. Clean. Prod. https://doi.org/10.1016/ j.jclepro.2016.04.046.

Chen, G., Wiedmann, T., Hadjikakou, M., Rowley, H., 2016b. City carbon footprint networks. Energies 9, 602. https://doi.org/10.3390/en9080602.

Dameno, A., 2016. Estimación de las Emisiones Indirectas de la Ciudad de Madrid. Trabajo Fin de Grado. Escuela Técnica Superior de Ingenieros Industriales. Universidad Politécnica de Madrid (UPM), Espana.

Davis, S.J., Caldeira, K., 2010. Consumption-based accounting of $\mathrm{CO}_{2}$ emissions. PNAS 107 (12), 5687-5692.

Ecoinvent, 2016. Life Cycle Inventory Database. version 3.2. http://www.ecoinvent. org. (Accessed 14 September 2016).

EEA (European Environment Agency), 2013. EMEP/EEA Air Pollutant Emission Inventory Guidebook 2013: Technical Guidance to Prepare National Emission Inventories. http://www.eea.europa.eu/publications/emep-eea-guidebook2013. (Accessed 19 May 2016)

Eichner, T., Pethig, R., February 1, 2009. Carbon Leakage, the Green Paradox and Perfect Future Markets. CESifo Working Paper Series No. 2542. https://ssrn.com/ abstract $=1340394$. (Accessed 20 November 2016).

Greater London Authority, 2011. London's Wasted Resource. The Mayor's Municipal Waste Management Strategy. https://www.london.gov.uk/sites/default/files. pdf. (Accessed 5 May 2016).

Greater London Authority, 2014. Assessing London's Indirect Carbon Emissions 2010. www.london.gov.uk. (Accessed 5 May 2016)

Harris, P.G., Chow, A.S.Y., Symons, J., 2012. Greenhouse gas emissions from cities and regions: international implications revealed by Hong Kong. Energy Policy 44 (1), 416-424.

Hillman, T., Ramaswami, A., 2010. Greenhouse gas emission footprints and energy use benchmakrs for eigth U.S. Cities. Environ. Sci. Technol. 44 (6), 1902-1910.

Hoornweg, D., Sugar, L., Gomez, C.L.T., 2011. Cities and greenhouse gas emissions: moving forward. Environ. Urban. 23 (1), 207-227.

Kunanuntakij, K., Varabuntoonvit, V., Vorayos, N., Panjapornpon, C., Mungcharoen, T., 2017. Thailand green GDP assessment based on environmentally extended input-output model. J. Clean. Prod. https://doi.org/10.1016/ j.jclepro.2017.02.106.
Larsen, H.N., Solli, C., Pettersen, J., 2012. Supply chain management: how can we reduce our energy/climate foot print. Energy Procedia 20 (1), 354-363.

Larsen, H.N., Hertwich, E.G., 2009. The case for consumption-based accounting of greenhouse gas emissions to promote local climate action. Environ. Sci. Policy 12 (7), 791-798.

Larsen, H.N., Hertwich, E.G., 2010a. Identifying important characteristics in municipal carbon footprints. Ecol. Econ. 70 (1), 60-66.

Larsen, H.N., Hertwich, E.G., 2010b. Implementing Carbon Footprint-based calculation tools in municipal GHG inventories: the case of Norway. J. Ind. Ecol. 14 (6), 965-977.

Larsen, H.N., Hertwich, E.G., 2011. Analyzing the carbon footprint from public services provided by counties. J. Clean. Prod. 19 (1), 1975-1981.

Lumbreras, J., Garcia-Martos, C., Mira, J., Borge, R., 2009. Computation of uncertainty for atmospheric emission projections from key pollutant sources in Spain. Atmos. Environ. 43, 1557-1564.

Lumbreras, J., Andres, J.M., Perez, J., Borge, R., Paz, D., Rodriguez, M.E., 2015. A methodology to estimate uncertainty for emission projections through sensitive analysis. J. Air Waste Manag. Assoc. 65 (4), 384-394.

Madrid, 2011a. Inventory of Madrid City GHG Emissions 2010. http://www.madrid es/Unidades/Sostenibilidad.pdf. (Accessed 5 May 2016).

Madrid, 2011b. Memoria de Actividades de la Dirección General del Parque Tecnológico de Valdemingómez - ano 2010. http://www.madrid.es/ UnidadesDescentralizadas/Valdemingomez.pdf. (Accessed 5 May 2016).

Madrid, 2012. Plan de Calidad del Aire de la Ciudad de Madrid 2012-2015. Madrid City Council. http://www.jenasa.com/wp-content/uploads/2012/05/plan_de_ calidad_del_aire_Madrid_2011-2015.pdf. (Accessed 12 June 2016).

Madrid, 2014. Plan de Uso Sostenible de la Energía y Prevención del Cambio Climático de la Ciudad de Madrid - 2020. http://www.madrid.es/ UnidadesDescentralizadas/Sostenibilidad.pdf. (Accessed 5 May 2016).

Madrid, 2015. GPC Reporting of Madrid 2013 (unpublished manuscript).

Madrid, 2017. Plan de Calidad del Aire y Cambio Climático de la Ciudad de Madrid. http://www.madrid.es/UnidadesDescentralizadas/Sostenibilidad.pdf. (Accessed 5 April 2017)

Meng, J., Mi, Z., Yang, H., Shan, Y., Guan, D., Liu, J., 2017. The consumption-based black carbon emissions of China's megacities. J. Clean. Prod. https://doi.org/ 10.1016/j.jclepro.2017.02.185.

Mi, Z.-F., Pan, S.-Y., Yu, H., Wei, Y.-M., 2015a. Potential impacts of industrial structure on energy consumption and $\mathrm{CO}_{2}$ emission: a case study of Beijing. J. Clean. Prod. 103, 455-462.

Mi, Z.-F., Wei, Y.-M., He, C.-Q., Li, H.-N., Yuan, X.-C., Liao, H., 2015b. Regional efforts to mitigate climate change in China: a multi-criteria assessment approach Mitig. Adapt. Strateg. Glob. Change. https://doi.org/10.1007/s11027-015-9660-1.

Mi, Z., Zhang, Y., Guan, D., Shan, Y., Liu, Z., Cong, R., Yuan, X.-C., Wei, Y.-M., 2016. Consumption-based emission accounting for Chinese cities. Appl. Energy. https://doi.org/10.1016/j.apenergy.2016.06.094.

Minx, J., Baiocchi, G., Wiedman, T., Barrett, J., Creutzig, F., Feng, K., Forster, M. Picheler, P., Weisz, H., Hubacek, K., 2013. Carbon footprints of cities and other human settlements in the UK. Environ. Res. Lett. 8 (1), 35-39.

Morilla, C.R., Díaz-Salazar, G.L., 2004. Matriz de contabilidad social y medioambiental: Aplicación a las emisiones de gases efecto Invernadero de la Economía Española del año 2000. FEDEA, Espana.

Morilla, C.R., 2010. Sistema híbrido para el análisis de las relaciones entre e medioambiente, la economía y la sociedad: aplicación para año 2000, al recurso del agua y las emisiones a la atmósfera en España. Tesis. IEA, Sevilla, Espana.

Oficemen (Agrupación de Fabricantes de Cemento de España), 2011. Informe de actividades 2010. https://oficemen/Informe.pdf. (Accessed 3 February 2017).

Perez, J., Lumbreras, J., Paz, D., Rodriguez, M.E., 2017a. Methodology to evaluate the environmental impact of urban solid waste containerization system: a case study. J. Clean. Prod. 150, 197-213.

Perez, J., Lumbreras, J., Rodriguez, M.E., Vedrenne, M., 2017b. A methodology for estimating the carbon footprint of waste collection vehicles under different scenarios: application to Madrid. Transp. Res. Part D 52, 156-171.

Peters, G.P., 2008. From production-based to CB national emission inventories. Ecol. Econ. 65 (1), 13-23.

Ramachandra, T.V., Aithal, B.H., Sreejith, K., 2015. Carbon footprints in major cities in India. Renew. Sustain. Energy Rev. 44, 473-495.

Schaltegger, S., Csutora, M., 2012. Carbon accounting for sustainability and management. Status quo and challenges. J. Clean. Prod. 36 (1), 1-16.

Scott, K.A., Barrett, J.R., 2013. Investigation into the Greenhouse Gas Emissions of the UK Services Industries. Report to the UK Department for Environment. University of Leeds.

Scott, K.A., Barrett, J.R., 2015. An integration of net imported emissions into climate change targets. Environ. Sci. Policy 52, 150-157.

SimaPro, 2016. LCA Software Package. Version 8.3.0, Pré Sustainability. https:// simapro.com. (Accessed 14 September 2016).

UNESID (Unión de Empresas Siderúrgicas), 2011. La Industria Siderúrgica Española 2010. https://unesid.org/iris2010.pdf. (Accessed 3 February 2017).

WRI (World Resources Institute), 2014. Global Protocol for Community-Scale Greenhouse Gas Emission Inventories: an Accounting and Reporting Standard for Cities. http://ghgprotocol.org/files.pdf. (Accessed 14 September 2016). 